\title{
Nuorten terveysvalintoihin liittyvät oikeudet, velvollisuudet ja vastuu
}

Nuorella on oikeus terveyteen. Tätä painottaa myös lasten oikeuksien julistus (1). Lasten ja nuorten oikeudet koskettavat merkittävää osaa maailman väestöstä (2). Yli puolet suomalaisista lapsista ei kuitenkaan tiedä, että heillä on erityisiä oikeuksia (3). Oikeus terveyteen luo pohjan, joka mahdollistaa myös terveysvalintojen toteuttamisen.

\section{NUORTEN TERVEYSVALINNAT}

Terveysvalinnoilla tarkoitetaan tietoisia ja välittömiä terveyteen liittyviä päätöksiä. Nämä kohdistuvat esimerkiksi ravitsemukseen ja tupakointiin. Terveysvalinnat tarkoittavat myös tiedostamattomia tai välillisiä valintoja. Tiedostamattomia valintoja ovat esimerkiksi terveyteen liittyvät tavat ja välillisiä päätökset siitä, käyttääkö pyöräillessä pyöräilykypärää. $(4,5)$

Terveysvalinnat ovat nuorelle mahdollisuus ylläpitää ja edistää terveyttä, mutta ne voivat myös altistaa terveysriskeille ja sairastumiselle (6). Valinnat voivat olla osa minäkuvan rakentamista, itsensä etsimistä sekä vapauden ja rajojen kokeilua. Lisäksi terveysvalinnat voivat olla osa yhteiskunnallista vaikuttamista, johon liittyy esimerkiksi huoli ympäristön tilasta. (7)

Terveysvalintojen toteuttaminen edellyttää kuitenkin tietoa (8), jotta nuori voi tehdä terveyttä edistäviä ja vastuullisia valintoja. Terveysvalinnat voivat pohjautua huolelliseen harkintaan, mutta myös hetkellisiin mielihaluihin, kavereiden vaikutukseen tai esimerkiksi kapinointiin vanhempia ja auktoriteetteja vastaan (4,7). Yksittäisillä, harmittomiltakin tuntuvilla valinnoilla voi kuitenkin olla pitkäaikaisia vaikutuksia nuoren terveyteen ja myöhempään hyvinvointiin $(9,10)$. Moni aikuisuuden terveyttä uhkaavista tavoista onkin saanut alkunsa nuoruuden terveysvalinnoista. Nuoren valinnoilla voi myös ol- la ylisukupolvisia vaikutuksia aina hänen omiin lapsiinsa saakka. (11)

Nuoruus on tasapainottelua itsenäisyyden ja rajoitusten välillä. Se on haavoittuvaista ja haasteellista aikaa, jossa tapahtuu merkittäviä ja kauaskantoisia fyysisiä ja psyykkisiä muutoksia $(12,13)$. Vanhempien rooli valintojen ohjaajina ja rajoittajina heikkenee ja oma ajattelu sekä ystävät ja kaverit ovat entistä merkityksellisempiä (14). Terveysvalinnoissa myös sosiaalinen media on osa nuoren arkea ja voi luoda odotuksia ja mielikuvia tavoiteltavasta ulkonäöstä tai elämäntavasta.

Terveysvalinnat eivät kuitenkaan ole vain itsenäisiä ja valitsijaan itseensä vaikuttavia päätöksiä (15). Valinnoilla voidaan vaikuttaa muihin ihmisiin ja esimerkiksi nuoren liikuntaharrastus tai kasvisruokavalio voi muuttaa koko perheen toimintatapoja. Toisaalta terveysvalinnat voivat vaarantaa toisten terveyden. Esimerkiksi tupakointi tai päihteiden käyttö voivat vaikuttaa välillisesti tai välittömästi myös lähipiiriin.

\section{NUORTEN OIKEUDET, VELVOLLISUUDET JA VASTUU OSANA ITSEMÄ̈̈RÄÄMISOIKEUTTA JA IHMISARVOA}

Nuorten terveysvalinnat perustuvat autonomiaan eli itsemääräämisoikeuteen. Tällä tarkoitetaan sitä, että nuorella on oikeus ja vapaus tehdä omia terveysvalintoja sekä osallistua itseään koskevaan päätöksentekoon. $(16,17)$

Oikeudet eivät kuitenkaan riitä, vaan ne kytkeytyvät läheisesti velvollisuuksiin $(18,19)$. Nuorella on velvollisuuksia itseä ja omaa terveyttä ja hyvinvointia kohtaan (20), mutta myös velvollisuus huomioida muut ihmiset terveysvalintoja tehdessään. Tähän sisältyy muun muassa velvollisuus auttaa muita. $(7,21)$ Oikeus tehdä omia valintoja johtaa velvollisuuteen kunnioittaa muiden ihmisten vastaavaa oikeutta $(18,19)$. 
Velvollisuudet varmistavat siten oikeuksien toteutumisen (16).

Nuoren oikeudet ja velvollisuudet liittyvät vastuuseen (22). Vastuu tarkoittaa sitä, että nuori huolehtii terveydestään ja sen edistämisestä. Sen lisäksi, että nuorella on vastuu itsestä ja omista valinnoista, hänellä on myös osaltaan vastuu muista ihmisistä ja heidän hyvinvoinnistaan. (23) Vastuu muista tarkoittaa sitä, että nuori huomioi, ettei vahingoita muita ihmisiä omilla valinnoillaan $(7,18,23)$.

Vaikka nuorella on oikeus terveyteen ja omiin terveysvalintoihinsa, hänellä on myös oikeus suojeluun terveytensä suhteen (24). Nuori ei pysty yksin saavuttamaan ja ylläpitämään terveyttä, vaan se edellyttää terveyttä tukevia ja mahdollistavia olosuhteita $(25,26)$. Vanhemmilla on vanhemmuutensa perusteella velvollisuus huolehtia nuoren terveellisestä arjesta ja terveydenhuollolla ja laajemmin yhteiskunnalla velvollisuus luoda ja turvata parhaat mahdolliset edellytykset terveelliseen elämään ja tulevaisuuteen (27). Nuoren suojelu tarkoittaa usein sitä, että hänellä ei ole vapautta tehdä millaisia terveysvalintoja tahansa, vaikka valinnat koskisivat vain nuorta itseään.

Suojelu ei kuitenkaan tarkoita sitä, että nuorella ei ole mahdollisuutta tehdä omia terveysvalintoja sekä harjoitella ja kasvaa vastuullisuuteen. Nuoret ovatkin kuvanneet, että kun he voivat harjoitella oikeuksien ja velvollisuuksien toteuttamista ja vastuunottoa, se on tukenut heidän kokemustaan itsenäisestä pärjäämisestä omassa elämässään (7). Keskeinen kysymys on kuitenkin se, millaiset oikeudet, velvollisuudet ja vastuu ovat nuoren terveyden kannalta hyväksi ja mitkä puolestaan kuuluvat aikuisille ja yhteiskunnalle?

Oikeudet, velvollisuudet ja vastuu kiteytyvät ihmisarvoon (17). Ihmisarvo perustuu siihen, että nuori huomioidaan oman terveytensä aktiivisena toimijana eikä pelkästään vastaanottavana sivustakatsojana (28). Ihmisarvo johtaa myös siihen, että nuorta tulee kohdella oikeudenmukaisesti ja häntä arvostetaan tasa-arvoisena yksilönä (16).

\section{NUORTEN TERVEYDEN EDISTÄMISEN AJANKOHTAISUUS}

Vaikka lasten oikeuksien julistus on lähes 60 vuoden takaa, se on edelleen ajankohtainen. Nuorten terveyteen ja terveysvalintoihin tulee kiinnittää huomiota, joskin länsimaissa nuoret vaikuttavat tekevän entistä parempia terveysvalintoja (6). Tätä tietoa vahvistaa muun muassa Terveyden ja hyvinvoinnin laitoksen (2017) toteuttama kouluterveyskysely. Aiempiin vuosiin verrattuna suomalaiset nuoret liikkuvat enemmän, syövät terveellisemmin ja käyttävät päihteitä vähemmän. (29)

Maailman terveysjärjestö (2016) on todennut, että yleisimmät nuorten terveyttä uhkaavat tekijät liittyvät ravitsemukseen. Näitä ovat sekä ylipaino, aliravitsemus että vähäinen liikunta sekä tupakointi ja päihteiden käyttö. (30)

Huolestuttavaa on se, että nuorten terveys ja hyvinvointi näyttävät jakautuvan $(25,30)$. Nuoret jotka voivat hyvin, voivat entistä paremmin ja pystyvät hyödyntämään tietoa, koulutusta ja yhteiskunnan palveluita terveysvalinnoissaan. Samaan aikaan pahoinvointi ja terveysongelmat kasautuvat toisille nuorille.

Nuoren terveysvalinnoissa on merkityksellistä se, että yksittäinen nuori ei kuitenkaan voi valita terveysvalintojensa lähtökohtia ja olosuhteita. Nuorilla on erilaiset mahdollisuudet tietoon ja koulutukseen, sosiaalisiin suhteisiin sekä sosioekonomiseen asemaan (11,30). Lähtökohtien erot näkyvät muun muassa elinajanodotteessa, joka vaihtelee sekä kansallisesti alueittain, että maailmanlaajuisesti (31). Elinympäristön turvallisuus sekä sen tarjoamat vaihtoehdot luovat perusolosuhteet terveysvalinnoille.

Huolestuttavaa on myös se, että lasten ja nuorten köyhyys on lisääntynyt ja vuonna 2018 julkaistun OECD:n raportin mukaan joka seitsemäs teollisuusmaiden lapsista elää köyhyydessä (32). Perheen taloudellinen tilanne määrittää esimerkiksi mahdollisuuksia hankkia terveellistä ruokaa kotiin, mutta myös nuoren harrastuksia. Oikeuksien, velvollisuuksien ja vastuun tarkastelussa on siten huomioitava nuoren yksilöllisten lähtökohtien lisäksi myös laajemmat sosiaaliset, taloudelliset ja ympäristölliset olosuhteet $(7,33)$.

\section{VÄITÖSKIRJATUTKIMUKSEN KOHTEENA NUORTEN TERVEYSVALINTOJEN EETTINEN PERUSTA}

Nuorten terveysvalintoja koskeva aikaisempi tutkimus on kohdistunut terveyskäyttäytymiseen, terveyteen liittyviin arvoihin, terveyskäsityksiin sekä laajemmin terveyden edistämiseen. Terveysvalintoihin liittyviä oikeuksia, vastuita ja velvollisuuksia on tarkasteltu aikuisten näkökulmasta, mutta tieto nuorten käsityksistä puuttuu (34). Koska nuoruus on terveysvalintojen suhteen eri- 
tyistä aikaa, ilmiön ymmärtäminen edellyttää, että nuorten omat käsitykset huomioidaan.

Väitöskirjatutkimuksessani tarkasteltiin nuorten terveysvalintoihin liittyviä oikeuksia, velvollisuuksia ja vastuuta (33). Nämä muodostavat osaltaan terveysvalintojen eettisen perustan. Tuotettu tieto on tarpeen, jotta aihealuetta voidaan nuorten näkökulmasta tunnistaa ja nimetä. Tietoa tarvitaan myös vahvistamaan nuorten osallisuutta ja aktiivisuutta oman terveyden edistämisessä.

Tutkimuksessani käytettiin monimenetelmäistä tutkimusasetelmaa. Ensimmäisessä osassa tuotettiin tietoa yksilön terveyteen liittyvästä vastuusta Sosiaali- ja terveysministeriön asiakirjoihin $(n=54)$ perustuen ja toisessa osassa kuvattiin nuorten terveysvalintoihin liittyviä oikeuksia, velvollisuuksia ja vastuuta aiemmassa kirjallisuudessa $(n=18)$. Koska aiempi tutkimustieto aihealueesta oli hajanaista, tutkimuksen kolmannessa osassa haastateltiin 9-luokkalaisia nuoria ( $\mathrm{n}=67)$ heidän käsityksistään ja kokemuksistaan nuorten oikeuksista, velvollisuuksista ja vastuusta. Neljännessä osassa laadittiin kyselylomake. Lomakkeen arvioivat asiantuntijaryhmät $(n=23)$ sekä 200 yhdeksäsluokkalaista suomalaista nuorta. (33)

Tutkimuksen tulosten mukaan nuorten terveysvalintoihin liittyvät oikeudet, velvollisuudet ja vastuu ovat tunnistettavia, mutta osin päällekkäisiä. Ne ovat kiinteä osa nuoren arkea ja vaikuttamista omaan terveyteensä. Nuori ei kuitenkaan ole yksin vastuussa terveydestään, vaan vanhemmat, terveydenhuolto ja laajemmin yhteiskunta ovat vastuussa siitä, että nuorella on mahdollisuuksia tehdä terveyttä edistäviä valintoja sekä saavuttaa ja toteuttaa niihin liittyviä oikeuksia, velvollisuuksia ja vastuuta. (33)

\section{LÄHTEET}

(1) Unicef. Declaration of the rights of the child. 1959.

(2) Suomen YK-liitto. Maailman väestö. 2018 Luettu 12.2.2019 https://www.ykliitto.fi/yk70v/ sosiaalinen/maailman-vaesto.

(3) Lastensuojelun keskusliitto. Lapsella on oikeus tulla kuulluksi. Kyselyraportti lapsen oikeuksista, toimintaympäristöstä ja osallisuudesta. 2017.

(4) Paternoster R., Pogarsky G. Rational choice, agency and thoughtfully reflective decision making: The short and long-term consequences of making good choices. J Quant Criminol 2009;25(2):103-27.

Doi: 10.1007/s10940-009-9065-y.

(5) Spencer G. The 'healthy self' and 'risky' young Other: young people's interpretations of health and health-related risks. Health Risk Soc 2013;15(5):449-62.

Doi: $10.1080 / 13698575.2013 .804037$.

(6) WHO. Adolescents: health risks and solutions. 2018. Luettu 20.10.2018. http://www.who.int/ mediacentre/factsheets/fs345/en/.

(7) Moilanen T., Pietilä A-M., Coffey M., Sinikallio S., Kangasniemi M. Adolescents' lived experiences of making health choices: an ethical point of view. Scand J Caring Sci 2018;32(2):914-23.

Doi: $10.1111 / \mathrm{scs} .12526$.

(8) Atkins R., Bluebond-Langner M., Read N., Pittsley J., Hart D. Adolescents as health agents and consumers: results of a pilot study of the health and health-related behaviors of adolescents living in a high-poverty urban neighborhood. J Pediatr Nurs 2010;25(5):38292. Doi: 10.1016/j.pedn.2009.07.001.

(9) Brown S., Shoveller J., Chabot C., LaMontagne AD. Risk, resistance and the neoliberal agenda: young people, health and well-being in the UK, Canada and Australia. Heal Risk Soc 2013;15(4):333-46.

Doi: $10.1080 / 13698575.2013 .796346$.

(10) Ridder M a. M., Heuvelmans M a., Visscher TLS., Seidell JC., Renders CM. We are healthy so we can behave unhealthily: a qualitative study of the health behaviour of Dutch lower vocational students. Health Educ 2010;110:30 42.

Doi: $10.1108 / 09654281011008735$.

(11) WHO. Coming of age: adolescent health. 2018. Luettu 20.10.2018. http://www.who.int/healthtopics/adolescents/coming-of-age-adolescenthealth.

(12) Hashmi S. Adolescence: an age of storm and stress. Rev Arts Humanit 2013;2(1):19-33.

(13) Steinberg L. Cognitive and affective development in adolescence. Trends Cogn Sci 2005;9(2):69-74.

Doi: 10.1016/j.tics.2004.12.005.

(14) Vera-Estay E., Dooley JJ., Beauchamp MH. Cognitive underpinnings of moral reasoning in adolescence: the contribution of executive functions. J Moral Educ 2015;44(1):17-33. Doi: 10.1080/03057240.2014.986077.

(15) Stead M., McDermott L., MacKintosh AM., Adamson A. Why healthy eating is bad for young people's health: identity, belonging and food. Soc Sci Med 2011;72(7):1131-9. Doi: 10.1016/j.socscimed.2010.12.029.

(16) Beauchamp TL., Childress JF. Principles of biomedical ethics. 7th ed. New York: Oxford University Press; 2012.

(17) Nordström K., Juth N., Kjellström S., Meijboom FLB., Görman U. Values at stake: autonomy, responsibility, and trustworthiness 
in relation to genetic testing and personalized nutrition advice. Genes Nutr 2013;8(4):365-72. Doi: 10.1007/s12263-013-0337-7.

(18) Kangasniemi M., Halkoaho A., LansimiesAntikainen H., Pietila A-M. Duties of the patient: a tentative model based on metasynthesis. Nurs Ethics 2012;19(1):58-67. Doi: 10.1177/0969733011412105.

(19) Nickel J. Human rights. The Stanford Encyclopedia of Philosophy. 2018. Luettu 24.4.2018. https://plato.stanford.edu/cgi-bin/ encyclopedia/archinfo.cgi? entry=rights-human.

(20) UNESCO. Report of the international bioethics committee of UNESCO (IBC) on social responsibility and health. Paris: United Nations Educational, Scientific and Cultural Organization; 2010.

(21) Hirjaba M., Haggman-Laitila A., Pietila A-M., Kangasniemi M. Patients have unwritten duties: experiences of patients with type 1 diabetes in health care. Heal Expect 2015;18(4):3274-85. Doi: 10.1111/hex.12317.

(22) Snelling PC. Who can blame who for what and how in responsibility for health? Nurs Philos 2015;16(1):3-18.

Doi: 10.1111/nup.12061.

(23) Snelling P. Saying something interesting about responsibility for health. Nurs Philos an Int J Healthc Prof 2012;13(3):161-78. Doi: 10.1111/j.1466-769X.2011.00531.x.

(24) United Nations. Convention on the rights of the child. 1990.

(25) Elgar FJ., Pförtner T-K., Moor I., De Clercq B., Stevens G., Currie C. Socioeconomic inequalities in adolescent health 2002-2010: a time-series analysis of 34 countries participating in the Health Behaviour in School-aged Children study. Lancet 2015;385(14):2088-296. Doi: 10.1016/S0140-6736(14)61460-4.

(26) WHO. Health for the world's adolescents a second chance in the second decade. Geneva; 2014.

(27) Moilanen T., Pietilä A-M., Kangasniemi M. Yksilön terveysvalinnat ja vastuu osana terveysministeriön informaatio-ohjauksesta. Sos Aikakausl 2015;52(4):268-81.

(28) Paul M. Rights. Arch Dis Child 2007;92(8):720-5.

Doi: 10.1136/adc.2005.091629.
(29) THL. Kouluterveyskyselyn tulokset nuorilla 2017. Terveyden ja hyvinvoinnin laitos. Luettu 22.4.2018. https://sampo.thl.fi/ pivot/ $\operatorname{prod} / \mathrm{fi} / \mathrm{ktk} / \mathrm{ktk} 1 /$ summary_perustulokset? alue_ $0=87869 \&$ mittarit_ $0=200537 \&$ mittarit_1= 200264\& mittarit_2= 200572\&vuosi_ 2017_0=v2017\#.

(30) WHO. Growing up unequal: gender and socioeconomic differences in young people's health and well-being. Heal Behav Sch Child Study Int Rep from 2013/2014 Surv 2016;(7). Doi: ISBN 9879289014236.

(31) Tilastokeskus. Vastasyntyneiden elinajanodote oli vuonna 2017 pojilla 78,7 ja tytöillä 84,2 vuotta. 2018. Luettu 12.2.2019. http://www.stat. fi/til/kuol/2017/01/kuol_2017_01_2018-10-26_ tie_001_fi.html.

(32) OECD. Poor children in rich countries: why we need policy action 2018;(October):1-8.

(33) Moilanen T. Ethical basis of adolescents health choices: focus on rights, duties and responsibilities. 2018. Itä-Suomen yliopisto, terveystieteiden tiedekunta. Publications of the Unversity of Eastern Finland. Dissertations in Health Sciences, 490.

(34) Moilanen T., Pietilä A-M., Coffey M., Kangasniemi M. Adolescents' health choices related rights, duties and responsibilities: an integrative review. Nurs Ethics 2018;25(4):418-35. Doi: $10.1177 / 0969733016654316$.

\section{Tanja Moilanen \\ TtT, projektitutkija \\ Itä-Suomen yliopisto \\ Hoitotieteen laitos}

Terveystieteiden maisteri Tanja Moilasen väitöskirja Ethical basis of adolescents' health choices: focus on rights, duties and responsibilities (Nuorten terveysvalintojen eettinen perusta: oikeudet, velvollisuudet ja vastuu) tarkastettiin Itä-Suomen yliopiston terveystieteiden tiedekunnassa 23.11. 2018. Vastaväittäjänä toimi emeritus professori Lasse Kannas Jyväskylän yliopistosta ja kustoksena dosentti Mari Kangasniemi Itä-Suomen yliopistosta. 